\title{
ASSERTIVE BEHAVIOR THERAPY \& POSITIVE REINFORCEMENT UNTUK MENINGKATKAN PERILAKU ASERTIF SISWA LEMBAGA BIMBINGAN BELAJAR Y
}

\author{
Elita Kirana ${ }^{1}$ dan Roslina Verauli ${ }^{2}$ \\ ${ }^{\mathbf{1}}$ Fakultas Psikologi, Universitas Tarumanagara Jakarta \\ Email: delicya.elita@gmail.com \\ ${ }^{2}$ Fakultas Psikologi, Universitas Tarumanagara Jakarta \\ Email: verauli@yahoo.com
}

\begin{abstract}
ABSTRAK
Perilaku asertif merupakan salah satu kemampuan yang diperlukan oleh anak usia sekolah agar dapat berprestasi di sekolah. Assertive Behavior Therapy (ABT) digunakan sebagai upaya untuk meningkatkan level perilaku asertif pada 5 anak perempuan kelas 3 SD di Lembaga Bimbingan Belajar Y yang berasal dari latar belakang sosial ekonomi rendah. Kelima anak ini memiliki gaya komunikasi yang pasif karena adanya rasa malu dan takut, sehingga memerlukan dorongan dari guru dan orang lain, sebelum menunjukkan kebutuhan dirinya. Partisipan mengikuti 6 sesi berupa kegiatan permainan dan praktek, dimana setiap tindakan asertif yang tampak akan mendapatkan positive reinforcement sosial berupa tepuk tangan dan pujian. Penelitian ini menggunakan quantitative one group pre-test post-test design dimana alat ukur Children's Assertiveness Inventory (CAI) dianalisa untuk mengetahui perbandingan hasil sebelum dan sesudah intervensi. Pada akhir sesi, total skor kelima partisipan mengalami peningkatan dibanding hasil skor sebelum, dan terdapat perubahan signifikan sesudah intervensi. Maka, Assertive Behavior Therapy dan Positive Reinforcement disimpulkan cukup efektif meningkatkan perilaku asertif pada lima siswa perempuan kelas 3 SD di Lembaga Bimbingan Belajar Y.
\end{abstract}

Kata kunci: Assertive behavior therapy, positive reinforcement, perilaku asertif, anak usia sekolah, bimbingan belajar

\section{PENDAHULUAN}

\section{Latar Belakang}

Anak yang berada pada rentang usia 6 sampai dengan 13 tahun berada pada tahapan middle childhood dan berada pada tahap sekolah, sehingga mereka dituntut untuk dapat melakukan tugastugas yang berkaitan dengan kognitif (Papalia, Olds \& Feldman, 2009). Kemampuan yang dimiliki anak akan berpengaruh terhadap prestasi belajar disekolah (Papalia \& Feldman, 2011). Anak usia sekolah mulai sadar akan kesuksesan dan kegagalannya, sehingga anak dapat mengevaluasi dirinya sendiri dan juga berasal dari penilaian orang lain. Mereka mampu menjelaskan keseluruhan perasaannya mengenai self esteem. Hal terpenting dari perkembangan self-esteem ini adalah anak selalu memberikan penilaian yang rendah terhadap dirinya sendiri.Salah satu pilar self esteem adalah perilaku asertif (Branden, 1995). Self esteem yang rendah pada anak cenderung mengembangkan gaya komunikasi pasif, dimana anak menyimpan opini untuk dirinya sendiri dan mencegah diri mengeluarkan emosi (Passive Communication, 2011). Anak dengan gaya komunikasi pasif juga tidak berani mengatakan apa yang ia butuhkan saat berada dalamproses pembelajaran, sehingga orang lain tidak memahami kebutuhannya. Anak juga seringkali menunjukkan sikap yang malu, takut dan pendiam sehingga tampak teralienasi dari teman di sekitarnya maupun guru di kelas (Dept. of Education \& Science, 1997).Literatur menunjukkan pentingnya proses belajar yang aktif, dimana siswa terikat dan terlibat dalam proses pembelajaran materi dibanding hanya pasif menerima (Boniecki \& Moore, 2003). Partisipasi siswa di kelas memfasilitasi murid mendapatkan pengetahuan dan mengembangkan kemampuan pemecahan masalah (Murray \& Lang, 1997). Sehingga, penting bagi siswa untuk mengembangkan gaya komunikasi yang baik, yaitu asertif. Asertif adalah perilaku yang memungkinkan seseorang untuk menyampaikan dan bertindak sesuai keinginannya sendiri tanpa kecemasan untuk mengungkap perasaannya secara jujur dan tidak melanggar hak orang lain (DeVito, 2013). Asertif juga 
dipahami sebagai mengerti apa yang dilakukan dan diinginkan, menjelaskannya pada orang lain, bekerja dengan cara kita sendiri untuk memenuhi kebutuhan kita sembari tetap menghormati orang lain. Orang yang asertif merupakan orang yang berani berinisiatif tanpa merugikan orang lain (Adams \& Lenz, 1995).

Perilaku asertif berdampak pada efektivitas seseorang dalam situasi sosial, dimana dampak positif ini dapat hilang jika seseorang memiliki kecemasan dalam situasi sosial (Gambril, 2006). Perilaku asertif adalah aspek dari kompetensi sosial yang berhubungan dengan adaptasi sosial dan realibiltias diri (Milovanovic, Miladinovic, dan Stojanovic, 2017). Kompetensi sosial ini melibatkan aspek kognitif, perilaku, dan faktor emosi.

Terdapat beberapa metode yang dikembangkan untuk mengembangkan kemampuan sosial ini pada anak, seperti token ekonomi, prompting rekan sebaya, modelling, coaching, social problem solving, dan pelatihan (Ollendick, 1983). Metode yang dipandang tepat untuk meningkatkan perilaku asertif adalah dengan menggunakan pelatihan perilaku asertif. Digunakannya pelatihan perilaku asertif karena dibutuhkan interaksi sosial secara langsung, dimana dalam peningkatan perilaku asertif ini membutuhkan keterlibatan peran orang lain sebagai pemberi respon dan sumber feed back. Sehingga dengan pelatihan ini, siswa dapat mengungkapkan perasaan, pikiran, pendapat secara langsung tanpa ada rasa cemas (Lioni \& Pratiwi, 2013). Trisnaningtyas, \& Nursalim (2010) sebelumnya telah melakukan penelitian mengenai pelatihan asertif dan dampaknya terhadap kemampuan komunikasi interpersonal, namun dengan modul pelatihan yang dikembangkan sendiri oleh peneliti.

Salah satu modul pelatihan Assertive Behavior Therapy yang berkembang adalah The Assertive Communication Training Game (Bickford, Miller, \&Rotheram-Borus, 1999; Rotheram, Armstrong,\& Booream, 1982, dalam Rotheram-Borus, Bickford, \& Milburn, 2001). Penelitian sebelumnya, penerapan Assertive Behavior Therapy diketahui meningkatkan kompetensi interpersonal, kepercayaan diri anak, harga diri, kontrol diri, dan menurunkan ketakutan serta kecemasan (Modahl, 2018).

Saat ini, Lembaga Bimbingan Belajar $\mathrm{Y}$ adalah sebuah komunitas sosial yang menyasar pendidikan, rutin mengadakan kursus pelajaran matematika dan bahasa Inggris bagi anak-anak di daerah sekitarnya, yaitu Jakarta Utara. Mayoritas murid adalah anak dari keluarga dengan status ekonomi rendah, dimana pekerjaan orang tuanya berkisar antara buruh, nelayan, sopir, tukang parkir, dan lainnya. Hal ini mengindikasikan anak yang berasal dari sosial ekonomi bawah cenderung membutuhkan pelatihan kepercayaan diri dan perilaku asertif (Berk, 2014).

Pada kelas sore, terdapat kurang lebih 25 siswa kelas 3 SD. Setiap kali pembelajaran berlangsung, tampak bahwa siswa di kelas terkelompokkan dalam 3 jenis komunikasi, yaitu anak agresif, asertif, dan pasif. Menurut pengajar, siswa yang pasif ini menunjukkan perilaku diam, tidak berani bertanya, tidak berinisiatif menjawab, dan pemalu saat mengerjakan tugas. Hal ini membuat pengajar tidak mengetahi tingkat pemahaman mereka sebenarnya. Saat tugas dikumpulkan, siswa ini cenderung mendapat nilai yang kurang baik. Pengajar harus berinisiatif menanyakan secara pribadi, barulah siswa-siswa ini akan mengeluarkan suaranya, walaupun seringkali dirasa sangat pelan. Saat pengajar meminta mereka menjawab pertanyaan, siswa ini cenderung menggelengkan kepala dan menolak, sehingga teman lain akan menertawakan. Menilik pada kurangnya kemampuan komunikasi sosial dapat menyebabkan perilaku maladaptif (Gambrill, 2006), maka perlu dilaksanakan proses terapi dengan pendekatan Assertive Behavior Therapy dan positive reinforcement untuk membangun sikap komunikasi asertif pada subyek. Pelatihan ini bertujuan mengembangkan sikap yang baik dalam berkomunikasi dengan orang lain dan meningkatkan kemampuan komunikasi subyek (Doverspike, 2014). Maka, tujuan dari penelitian ini adalah penerapan Assertive Behavior Therapy dan positive reinforcement untuk meningkatkan perilaku 
asertif pada siswa kelas 3 SD di Lembaga Bimbingan Belajar Y.

\section{METODE PENELITIAN \\ Partisipan penelitian}

5 orang anak perempuan yang berpartisipasi dalam penelitian ini memiliki karakteristik sebagai berikut: (a) duduk di kelas 3 SD, (b) mengikuti kursus di lembaga bimbingan belajar Y selama setidaknya 1 tahun, (c) memperoleh skor inteligensi dalam golongan rata-rata atau dibawah ratarata, dan memperoleh skor dibawah rata-rata $(<10)$ pada alat ukur Children's Assertiveness Inventory.

\section{Desain penelitian}

Penelitian ini menggunakan quantitative one group pre-test post-test design, dimana kuesioner Children's Assertiveness Inventory dianalisa untuk mengetahui perbandingan hasil sebelum dan sesudah pemberian intervensi.

\section{Lokasi penelitian}

Penelitian ini dilakukan di lembaga Bimbingan Belajar Y - yang diperuntukkan bagi anak-anak di lokasi dengan latar belakang ekonomi menengah ke bawah dan berada di daerah Jakarta Utara.

\section{Instrumen penelitian}

Peralatan yang digunakan dalam penelitian ini meliputi lembar informed consent, alat ukur Children's Assertiveness Inventory yang dikembangkan oleh Ollendick (1983), Culture Fair Intelligence Test, manual The Assertive Communication Training Game yang dikembangkan oleh Bickford, Miller, \& Rotheram-Borus, 1999; Rotheram, Armstrong,\& Booream, 1982 (dalam Rotheram-Borus, Bickford, \& Milburn, 2001), lembar observasi, lembar wawancara, lembar aktivitas, dan alat tulis.

\section{Pengukuran}

Children's Assertiveness Inventory digunakan untuk mengukur variabel dependen dari penelitian ini, yakni perilaku asertif. Alat ukur ini diterjemahkan ke Bahasa Indonesia oleh peneliti dan belum ada data mengenai validitas dan reliabilitasnya dalam versi Indonesia, karena sebelumnya belum pernah ada penelitian di Indonesia yang menggunakan alat ukur ini. Instrumen ini terdiri dari 14 item pertanyaan dengan pilihan jawaban ya dan tidak. 7 item mengukur inisiatif interaksi dan memberi atau menerima pujian, 7 item lain mengukur mempertahankan hak dan menolak permintaan. 8 item dengan jawaban "ya" menggambarkan perilaku asertif (contoh: "Saat kamu melakukan kesalahan kepada teman, apakah kamu meminta maaf?", sedangkan 6 item dengan jawaban "tidak" menggambarkan perilaku asertif (contoh: "Saat seseorang mengambil barang milikmu, apakah kamu akan membiarkannya?"). Selain itu, dilakukan pula observasi indikator perilaku yang mengacu pada dimensi perilaku asertif menurut Alberti \& Emmons (2002), yaitu mempromosikan kesetaraan hubungan manusia, bertindak menurut keinginan sendiri, membela diri sendiri, mengekspresikan perasaan dengan jujur dan nyaman, menyatakan pendapat, dan perhatian kepada hak orang lain. Observasi dilakukan dengan metode discrete categorization, yaitu metode asesmen perilaku pada perilaku yang dinilai secara dikotomi muncul atau tidak muncul. Metode ini sangat berguna saat harus menilai beberapa perilaku berbeda (Kazdin, 2013).

\section{Prosedur penelitian}

5 orang anak perempuan kelas 3 SD yang dirujuk oleh guru di lembaga bimbingan belajar Y kemudian mengikuti pre-test untuk mengetahui tingkat perilaku asertif mereka dengan administrasi skala Children's Assertiveness Inventory. Wawancara juga dilakukan dengan kelima 
anak untuk mengetahui gambaran partisipan. Alat ukur Children's Assertiveness Inventory akan kembali diadministrasikan setelah sesi terakhir intervensi dan dilaksanakan sebagai post-test. Hasil pre-test dan post-test kemudian akan dibandingkan untuk mengetahui dampak dari program intervensi terhadap tingkat perilaku asertif dari kelima anak. Sesi Assertive Behavior Therapy yang dilaksanakan berjumlah 6 sesi dengan rincian kegiatan terlampir pada Tabel 1, dengan setiap sesi berdurasi 45-60 menit.

Tabel 1

Rancangan Sesi Kegiatan Assertive Behavior Therapy

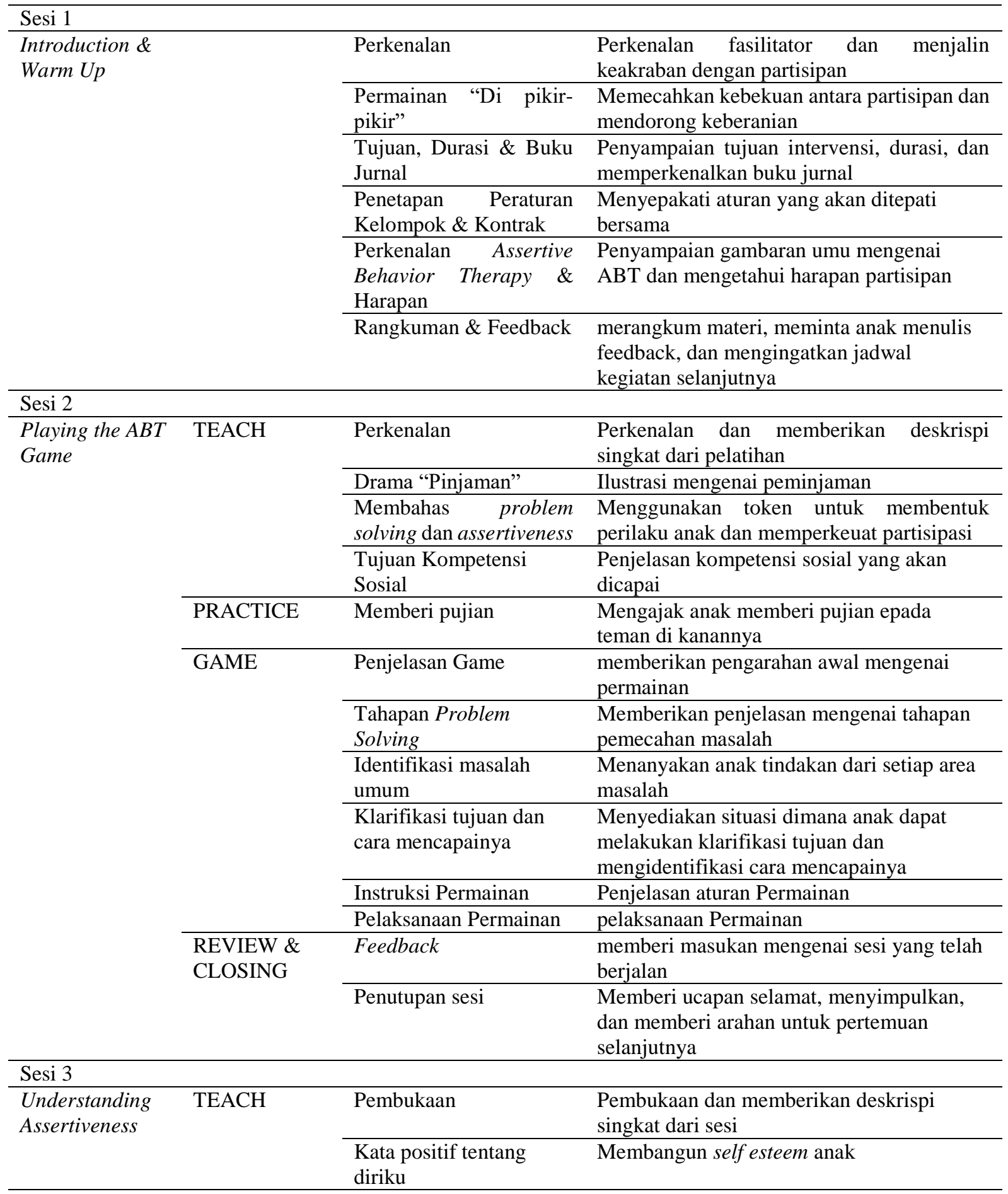




\begin{tabular}{|c|c|c|c|}
\hline & & Perkenalan Pemain & $\begin{array}{l}\text { Perkenalan tokoh ilustrasi perilaku agresif } \\
\text { dan pasif }\end{array}$ \\
\hline & & $\begin{array}{l}\text { "Who Has The } \\
\text { Answers?" }\end{array}$ & Drama perilaku pasif dan agresif \\
\hline & & $\begin{array}{l}\text { Eksplorasi Pasif \& } \\
\text { Agresif }\end{array}$ & $\begin{array}{l}\text { Mengeksplorasi demonstrasi perilaku pasif } \\
\text { dan agresif }\end{array}$ \\
\hline & & Pasif, Asertif \& Agresif & $\begin{array}{l}\text { Penjelasan mengenai pasif, asertif, dan } \\
\text { agresif }\end{array}$ \\
\hline & PRACTICE & Identifikasi & $\begin{array}{l}\text { Menanyakan pada anak tanda verbal dan } \\
\text { nonverbal dari pasif, agresif dan asertif }\end{array}$ \\
\hline & & $\begin{array}{l}\text { Latihan "Dapatkah saya } \\
\text { berdiri di depan anda?" }\end{array}$ & $\begin{array}{l}\text { Melatih anak mampu menyampaikan kalimat } \\
\text { asertif kepada orang lain }\end{array}$ \\
\hline & GAME & $\begin{array}{l}\text { Pembagian kelompok \& } \\
\text { Permainan }\end{array}$ & membagi kelompok dan instruksi permainan \\
\hline & & Situasi baru & $\begin{array}{l}\text { Memberikan kesempatan pada anak untuk } \\
\text { menyelesaikan masalah lain }\end{array}$ \\
\hline & $\begin{array}{l}\text { REVIEW \& } \\
\text { CLOSING }\end{array}$ & Feedback & $\begin{array}{l}\text { Pemberian feedback untuk mendorong } \\
\text { berbagi dan belajar dari } 1 \text { sama lain dengan } \\
\text { menggunakan token }\end{array}$ \\
\hline & & Penutupan sesi & $\begin{array}{l}\text { Memberi ucapan selamat, menyimpulkan, } \\
\text { dan memberi arahan untuk pertemuan } \\
\text { selanjutnya }\end{array}$ \\
\hline Sesi 4 & & & \\
\hline Making Request & TEACH & Pembukaan & $\begin{array}{l}\text { Pembukaan dan memberikan deskrispi } \\
\text { singkat dari sesi }\end{array}$ \\
\hline & & Memuji Teman & $\begin{array}{l}\text { Memberikan pujian kepada diri dan teman } \\
\text { sebagai bentuk membangun self esteem }\end{array}$ \\
\hline & & Review Assertiveness & $\begin{array}{l}\text { Membahas materi mengenai pasif, agresif, } \\
\text { dan asertif pada sesi sebelumnya }\end{array}$ \\
\hline & & $\begin{array}{l}\text { Mini Play: "Asking The } \\
\text { Teacher" }\end{array}$ & Melakukan role play \\
\hline & & Determine & $\begin{array}{l}\text { Meminta anak menentukan perilaku agresif } \\
\text { dan asertif }\end{array}$ \\
\hline & & Cara Meminta Tolong & $\begin{array}{l}\text { Menjelaskan cara meminta sesuatu dengan } \\
\text { kata "Saya mau..." }\end{array}$ \\
\hline & PRACTICE & Latihan Asertif & $\begin{array}{l}\text { Membagi anak dalam kelompok, kemudian } \\
\text { melatuh melakukan permintaan asertif }\end{array}$ \\
\hline & GAME & Permainan & $\begin{array}{l}\text { Penyampaian situasi masalah dan meminta } \\
\text { anak memecahkannya }\end{array}$ \\
\hline & REVIEW \& & Feedback & Memberikan masukan bagi jawaban anak \\
\hline & CLOSING & Kesimpulan \& Pujian & $\begin{array}{l}\text { Menyimpulkan isi sesi dan memberikan } \\
\text { pujian atas sesi yang telah terlaksana }\end{array}$ \\
\hline Sesi 5 & & & \\
\hline $\begin{array}{l}\text { Refusing } \\
\text { Request }\end{array}$ & TEACH & Pembukaan & $\begin{array}{l}\text { Pembukaan dan memberikan deskrispi } \\
\text { singkat dari sesi }\end{array}$ \\
\hline & & Memuji Teman & $\begin{array}{l}\text { Memberikan pujian kepada diri dan teman } \\
\text { sebagai bentuk membangun self esteem }\end{array}$ \\
\hline & & Review Konsep & $\begin{array}{llll}\begin{array}{l}\text { Membahas mengenai materi dari sesi } \\
\text { sebelumnya }\end{array} & & & \\
\end{array}$ \\
\hline & & Perkenalan Scene 1-3 & Role play 3 macam cara menolak permintaan \\
\hline & & Pembahasan & $\begin{array}{l}\text { Mencari tau penggunaan kalimat efektif } \\
\text { dalam scene } 1-3\end{array}$ \\
\hline & & Menolak Permintaan & $\begin{array}{l}\text { Menjelaskan bagaimana menolak } \\
\text { permintaan }\end{array}$ \\
\hline & PRACTICE & $\begin{array}{l}\text { Berlatik } \\
\text { permintaan }\end{array}$ & Anak berlatih menolak permintaan \\
\hline & GAME & Permainan & $\begin{array}{l}\text { Penyampaian situasi masalah dan meminta } \\
\text { anak memecahkannya }\end{array}$ \\
\hline
\end{tabular}




\begin{tabular}{|c|c|c|c|}
\hline & $\begin{array}{l}\text { REVIEW \& } \\
\text { CLOSING }\end{array}$ & Ringkasan \& Pujian & $\begin{array}{l}\text { Menyimpulkan isi sesi dan memberikan } \\
\text { pujian atas sesi yang telah terlaksana }\end{array}$ \\
\hline \multicolumn{4}{|l|}{ Sesi 6} \\
\hline \multirow[t]{6}{*}{ Termination } & & Pembukaan & $\begin{array}{l}\text { Mengetahui ingatan partisipan mengenai sesi } \\
\text { sebelumnya }\end{array}$ \\
\hline & & Review & $\begin{array}{l}\text { Mengetahui pemahaman partisipan mengenai } \\
\text { keseluruhan materi terapi }\end{array}$ \\
\hline & & Evaluasi & $\begin{array}{l}\text { Melihat manfaat yang diperoleh partisipan } \\
\text { dari sesi terapi yang telah dilalui }\end{array}$ \\
\hline & & Post Test & $\begin{array}{l}\text { Mendapatkan data post test berupa DAP dan } \\
\text { skala asertivitas }\end{array}$ \\
\hline & & Appreciation & Menyampaikan apresiasi kepada partisipan \\
\hline & & Penutup & $\begin{array}{l}\text { Memberi ucapan selamat, menyimpulkan, } \\
\text { dan memberi arahan untuk mengisi buku } \\
\text { jurnal }\end{array}$ \\
\hline
\end{tabular}

\section{HASIL PEMBAHASAN \& DISKUSI}

Intervensi kelompok ini dilakukan untuk meningkatkan perilaku asertif 5 orang anak perempuan kelas 3 SD yang merupakan siswa di lembaga bimbingan belajar Y dengan menerapkan Assertive Behavior Therapy dan positive reinforcement. 5 orang subyek awalnya menunjukkan sikap nonasertif, yaitu selalu khawatir dalam komunikasi, banyak meminta maaf, dan pemalu (Sims, 2017). Hal ini tampak dari hasil pengukuran pre test seluruh subjek yang berada di bawah rata-rata.

Pengukuran terhadap total skor Children's Assertiveness Inventory yang diperoleh kelima partisipan sebelum dan sesudah mengikuti 6 sesi intervensi menunjukkan adanya peningkatan (lihat Tabel 2). Subyek A, C, F, dan W mendapat skor post-test lebih tinggi dari skor rata-rata, yaitu lebih tinggi dari 10, sehingga ke-4 subjek tergolong dalam kategori asertif. Sementara itu, N walaupun mengalami peningkatan skor dari 6 ke 8, namun masih berada pada kategori dibawah rata-rata.

Tabel 2

Perbandingan Skor CAI subyek pada pre-test dan post-test

\begin{tabular}{cccccccccccc}
\hline & $\mathrm{A}$ & & \multicolumn{2}{c}{$\mathrm{C}$} & \multicolumn{2}{c}{$\mathrm{F}$} & \multicolumn{2}{c}{$\mathrm{W}$} & \multicolumn{2}{c}{ pre } \\
\hline & pre & post & pre & post & pre & post & pre & post & prt \\
\hline CAI & 9 & 11 & 8 & 14 & 6 & 12 & 6 & 8 & 7 & 12 \\
\hline
\end{tabular}

Terdapat perubahan signifikan pada mean skor total dari CAI kelompok pada pada post-test jika dibandingkan dengan mean pada skor CAI kelompok saat pre-test, yaitu dari mean 7,2 ke 11,4 (lihat grafik 1). Skor mean post-test ini lebih tinggi dari skor rata-rata, yaitu 10.

Grafik 1. Perbandingan Pre-test dan post test skala CAI

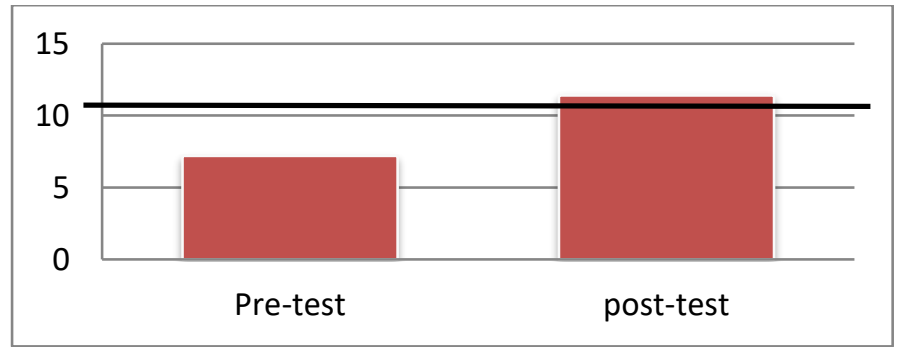


Berdasarkan hasil ini, dapat disimpulkan bahwa efektivitas dari Assertive Behavior Therapy dan positive reinforcement tergolong cukup baik untuk meningkatkan perilaku asertif. Hasil ini dipengaruhi oleh beberapa faktor. Pertama, adanya faktor kesamaan kriteria dari partisipan. Persamaan ini menimbulkan rasa solidaritas dan rasa nyaman satu sama lain. Hal ini meningkatkan kedekatan antar anggota karena perasaan setara dalam menghadapi masalah yang sulit (MacKenzie, dalam Hersen \& Sledge, 2002). Pelaksanaan pelatihan yang menyediakan informasi, contoh perilaku asertif, dan mencoba interaksi asertif diketahui membantu partisipan tidak hanya belajar apa yang harus ia katakan, namun juga belajar bagaimana mengatakannya (Speed, Goldstein, \& Goldfried, 2017).

Selain itu, kelompok yang tergolong kecil dibandingkan kelompok besar mempengaruhi kondisi partisipan, dimana partisipan lebih mudah mendapatkan perhatian. Faktor lain adalah pemberian timbal balik langsung berupa tepuk tangan, tos, dan pujian. Pemberian positive reinforcement diketahui membantu meningkatkan prestasi akademik dan self esteem pada anak. Hal ini juga memberi dampak jangka panjang bagi anak, yaitu dorongan untuk melakukan tindakan tersebut (Morin, 2017). Uraian hasil penelitian ini sejalan dengan hasil penelitian sebelumnya, bahwa pemberian latihan asertif berpengaruh pada peningkatan keterampilan komunikasi interpersonal siswa, sehingga siswa mampu berkata tidak, menyampaikan permintaan, mengekspresikan perasaan positif ataupun negatif, serta memulai dan mengakhiri percakapan (Trisnaningtyas, \& Nursalim, 2010).

Hasil temuan pada penelitian ini menambah jumlah literatur mengenai Assertive Behavior Therapy dan positive reinforcement pada populasi middle childhood yang hingga saat ini tergolong terbatas. Meskipun demikian, penelitian ini masih jauh dari kata sempurna. Terdapat beberapa keterbatasn dari penelitian ini, seperti tidak adanya control group pembanding serta jumlah sampel yang kecil. Waktu dan dana yang terbatas juga mengakibatkan tidak adanya uji validitas dan reliabilitas pada alat ukur yang digunakan dalam penelitian.

\section{Keterbatasan Penelitian}

Penelitian ini tentunya tidak lepas dari keterbatasan. Salah satu keterbatasan yang mendasar adalah penggunaan alat ukur yang belum diterjemahkan secara resmi dan belum adanya data reliabilitas serta validitasnya dalam versi Bahasa Indonesia. Alat ukur yang digunakan juga tidak memiliki data lengkap mengenai kategori skor maupun standar perubahan skor yang digunakan untuk menentukan perubahan sikap asertif seseorang. Selain itu, waktu pelaksanaan sesi cenderung tidak konsisten satu sama lain. Tempat pelaksanaan intervensi juga kurang memadai karena keterbatasan tempat pada lembaga tersebut.

Ucapan Terima Kasih (Acknowledgement)

Peneliti mengucapkan terima kasih kepada seluruh partisipan yang sudah bersedia berpartisipasi dalam penelitian kali ini dan pihak-pihak yang telah membantu dalam penyusunan artikel ini.

\section{KESIMPULAN \& SARAN}

\section{Kesimpulan}

Hasil penelitian ini menunjukkan bahwa penerapan Assertive Behavior Therapy dan positive reinforcement tergolong cukup baik untuk meningkatkan perilaku asertif pada anak usia sekolah.

\section{Saran}

Saran yang dapat diberikan oleh peneliti bagi penelitian selanjutnya, antara lain: (a) Pelaksanaan 
sesi dengan jadwal antar sesi yang berjarak konsisten, (b) Pelaksanaan sesi pada setting lokasi yang lebih memadai dan meminimalisir distraksi bagi partisipan dalam mengikuti kegiatan, (c) Jumlah sesi intervensi yang lebih banyak sehingga materi yang disampaikan lebih komprehensif bagi partisipan, (d) Melaksanakan penelitian dengan jumlah sampel yang lebih besar.

\section{Ucapan Terima Kasih}

Peneliti mengucapkan terima kasih kepada partisipan yang telah bersedia mengikuti sesi dan diwawancara. Selain itu, peneliti juga mengucapkan terima kasih bagi Lembaga Bimbingan Belajar Y yang bersedia memfasilitasi dan menjadi tempat penelitian.

\section{REFERENSI}

Adam, L. \& Lenz, E. (1995). Jadilah diri anda sendiri: Be your best. Efektivitas pribadi dalam hidup dan hubungan anda. Jakarta: Gramedia Pustaka Utama.

Alberti, R. \& Emmons, M. (2002). Your perfect right, hidup lebih bahagia dengan menggunakan hak. Jakarta: Elex Media Komputindo

Berk, L. E. (2014). Development through the lifespan (6th ed.). Boston: Pearson Education.

Boniecki, K. A., \& Moore, S. (2003). Breaking the silence: Using a token economy to reinforce classroom participation. Teaching of Psychology, 30(3), 224-227.

Branden, N. (1995). The six pillars of self-esteem. Bantam Dell Publishing Group.

Dept. of Education \& Science. (1997). On My Own Two Feet: Assertive Communication. Diunduh dari https://www.google.co.id/url?sa=t\&rct=j\&q=\&esrc=s\&source=web\& $\mathrm{cd}=1 \& \mathrm{cad}=\mathrm{rja} \& u a c t=8 \& \mathrm{ved}=0$ ahUKEwiT4ePN4_HXAhVEq48KHUXJB3gQFggoMAA\&ur $\mathrm{l}=\mathrm{http} \% 3 \mathrm{~A} \% 2 \mathrm{~F} \% 2 \mathrm{Fwww} . \mathrm{sphe.ie} \% 2 \mathrm{Fdownloads} \% 2 \mathrm{Fmo} 2 \mathrm{f} \% 2 \mathrm{Fassertive}$ _communication.pdf \&usg=AOvVaw01_ngjAU-jWtsmtBAKnDB3.

DeVito, J.A. (2013). The Interpersonal communication book (13th ed.). Boston: Pearson

Doverspike, W. F. (2013). How to be more assertive: a key to better communication. Diunduh dari https://www.google.co.id/url?sa=t\&rct=j\&q=\&esrc=s\&source=web\& $\mathrm{cd}=1 \& \mathrm{cad}=\mathrm{rja} \& u a c t=8 \& \mathrm{ved}=0$ ahUKEwixxofT6fHXAhUIpo8KHUB1DjkQFggoMAA\&url $=$ http $\% 3 \mathrm{~A} \% 2 \mathrm{~F} \% 2 \mathrm{Fdrwilliamdoverspike.com} \% 2 \mathrm{Ffiles} \% 2 \mathrm{Fhow}$ to_be_more_assertive.pdf\&us g=AOvVaw2So_BTYKpqwbxlAB1TYg24.

Gambrill, E. (2006). Critical thinking in clinical practice: Improving the quality of judgments and decisions. John Wiley \& Sons.

Hersen, M., \& Sledge, W. H. (2002). Encyclopedia of psychotherapy. USA: Elsevier

Kazdin, A. E. (2013). Behavioral modification in applied setting. Long Grove: Waveland Press, Inc.

Lioni, A., \& Pratiwi, T. I. (2013). Penerapan assertive training untuk mengurangi perilaku negatif berpacaran pada siswa kelas x-1 di sma negeri 1 porong. Jurnal Mahasiswa Teknologi Pendidikan, 4(1).

Milovanovic, R., Miladinovic, I. C., \& Stojanovic, B. (2017). Assertiveness of prospective teachers and preschool teachers. Journal Plus Education, 16(2), 289-303.

Modahl, C. (2018). A Bullying Prevention Program: Pairing Assertiveness Training to Empower Bully Victims. (Doctoral dissertation). Capella University.

Morin, D. (2017). The effects of inclusion and positive reinforcement within the classroom. Merrimack College.

Murray, H., \& Lang, M. (1997). Does classroom participation improve student learning. Teaching and Learning in Higher Education, 20(1), 7-9.

Ollendick, T. H. (1983). Reliability and validity of the revised fear survey schedule for children (FSSC-R). Behaviour research and therapy, 21(6), 685-692. 
Papalia, D.E. \& Feldman, R.D. (2011). A childs world : infancy through adolescence. Boston : McGraw Hill.

Papalia D.E., Olds, S.W, \& Feldman, R.D. (2009). Human Development (10th ed.) (Perkembangan Manusia edisi 10 buku 2). Jakarta: Salemba Humanika.

Rotheram-Borus, M. J., Bickford, B., \& Milburn, N. G. (2001). Implementing a classroom-based social skills training program in middle childhood. Journal of Educational and Psychological Consultation, 12(2), 91-111.

Sarafino, E. P. (2014). Health psychology: Biopsychosocial interactions (7th ed.). Diunduh dari https://books.google.co.id/books?id=m9hwDFOU1E8C\&pg=PT249\&lpg=PT249\&dq=source + of++external+distraction+during++psychological+intervention \&source $=$ bl\&ots $=5 \mathrm{SxeTeJcV}$ x\&sig=liAoofF8XKsqQzIoJjS02TopYX8\&hl=en\&sa=X\&ved=0ahUKEwi68d-1p-

TUAhVJKY8KHXccDgsQ6AEIQjAF\#v=onepage\&q=source of external distraction during psychological intervention $\& \mathrm{f}=$ false.

Sims, C. M. (2017). Do the big-five personality traits predict empathic listening and assertive communication?. International Journal of Listening, 31(3), 163-188.

Speed, B. C., Goldstein, B. L., \& Goldfried, M. R. (2017). Assertiveness Training: A Forgotten Evidence-Based Treatment. Clinical Psychology: Science and Practice.

Trisnaningtyas, E., \& Nursalim, M. (2010). Penerapan latihan asertif untuk meningkatkan keterampilan komunikasi interpersonal siswa. Jurnal Psikologi Pendidikan dan Bimbingan, 11(1), 30-35. 